\title{
HUBUNGAN PENGETAHUAN INFORMASI OBAT DENGAN KEPATUHAN MINUM OBAT PASIEN GANGGUAN JIWA DI PROVINSI LAMPUNG
}

\section{DRUG KNOWLEDGE-RELATED MEDICATION ADHERENCE IN PSYCHIATRY PATIENTS IN LAMPUNG PROVINCE}

\author{
Isnenia \\ Diploma III Farmasi Politeknik Kesehatan Tanjungkarang, Bandar Lampung \\ Jl. Soekarno Hatta No 1, 35144, Indonesia \\ *Penulis Korespondensi, e-mail: isnenia@ poltekkes-tjk.ac.id
}

\begin{abstract}
ABSTRAK
Pada saat ini secara global gangguan kesehatan jiwa menjadi tantangan kesehatan dan menyebabkan beban penyakit sebesar $14 \%$. Kondisi penyakit diperparah akibat ketidakpatuhan karena kurangnya pengetahuan. Ketidakpatuhan pasien dengan gangguan kesehatan jiwa berkisar antara 30-65\%. Keluarga pasien sebagai pendamping minum obat pasien harus mempunyai pengetahuan yang baik tentang penggunaan obat. Tujuan penelitian ini untuk mengetahui hubungan antara pengetahuan informasi obat dengan kepatuhan minum obat. Penelitian ini merupakan penelitian kuantitatif dengan desain analitik secara case control, dengan 360 sampel yang merupakan keluarga pasien. Pengetahuan keluarga pasien tentang informasi obat diperoleh dari kuesioner, sedangkan kepatuhan diukur menggunakan MMAS-8. Data dianalisis secara deskriptif meliputi karakteristik dan distiribusi pengetahuan serta kepatuhan. Regresi logistik uji omnibus digunakan untuk mengetahui hubungan karakteristik terhadap pengetahuan dan uji Kolmogorov-Smirnov untuk menguji hubungan pengetahuan terhadap kepatuhan. Tingkat pengetahuan keluarga pasien menunjukkan bahwa $357(99,8 \%)$ orang responden dengan tingkat pengetahuan suboptimal dan $3(0,8 \%)$ orang responden dengan pengetahuan optimal. Tingkat kepatuhan pasien menunjukkan 243 (67,5\%) dengan tingkat kepatuhan baik, $56(15,6 \%)$ sedang, dan $61(16,9 \%)$ rendah. Faktor sosioekonomi-klinis keluarga dan pasien tidak berhubungan signifikan dengan tingkat kepatuhan minum obat $(\mathrm{p}=0,964>0,05)$; dan tingkat pengetahuan terhadap tingkat kepatuhan $(\mathrm{p}=0,594>0,05)$ mempunyai hubungan tidak signifikan. Kesimpulan penelitian ini yaitu tidak terdapat hubungan bermakna antara tingkat pengetahuan keluarga pasien dengan kepatuhan pasien.
\end{abstract}

Kata kunci: pengetahuan informasi obat, kepatuhan, gangguan jiwa

\section{ABSTRACT}

Nowadays, mental health problems globally are considered as health challenge and cause a disease burden as much as 14\%. The disease condition is exacerbated by noncompliance due to lack of knowledge. The non-compliance of patients with mental health problems ranged from 30-65\%. The patient's family as a companion to take medication for the patient must have good knowledge about drug use. The aim of this study was to determine the relationship between knowledge of drug information and medication 
adherence. This study was a quantitative study with a case control analytic design, with 360 samples belonging to the patient's family. Knowledge of the patient's family about drug information was obtained from a questionnaire, while compliance was measured using MMAS-8. Data were analyzed descriptively including the characteristics and distribution of knowledge and compliance. The omnibus logistic regression test was used to determine the relationship between characteristics and knowledge and the Kolmogorov-Smirnov test to test the relationship between knowledge and compliance. The knowledge level of the patient's family indicated that 357 (99.8\%) respondents with suboptimal knowledge level and $3(0.8 \%)$ respondents with optimal knowledge. Patient adherence level showed 243 (67.5\%) with good adherence level, 56 (15.6\%) moderate, and 61 (16.9\%) low level of adherence. There was no significant association between family socio-economic-clinical factors and patients with the level of medication adherence ( $p=0.964>0.05)$; and there was no significant relationship between the level of knowledge and the level of compliance $(p=0.594>0.05)$. The conclusion is there was no significant relationship between the level of knowledge of the patient's family and patient adherence.

Keywords: knowledge of drug information, adherence, psychiatry disorders

\section{PENDAHULUAN}

Gangguan kesehatan jiwa dewasa ini menjadi tantangan kesehatan dan berkontribusi $14 \%$ ke beban penyakit secara global. Sekitar 450 juta orang dinyatakan menderita gangguan kejiwaan. Gangguan kejiwaan merupakan penyebab utama kecacatan dalam jangka waktu lama dan bersifat ketergantungan (Semahegn et al., 2018). Faktor yang dapat mempengaruhi kejadian gangguan kejiwaan antara lain status ekonomi yang rendah, penggunaan alkohol, stress, krisis ekonomi, perang, wabah penyakit, gempa bumi (Marquez and Saxena, 2016). Selain itu, Indonesia memiliki berbagai faktor biologis, psikologis dan sosial dengan keanekaragaman penduduk maka akan memicu peningkatan jumlah gangguan jiwa yang akan berdampak pada penambahan beban negara dan penurunan produktivitas manusia (Kemenkes, 2016).

Pasien yang mengalami gangguan jiwa sebagian besar mengalami ketidakpatuhan pengobatan (Roy et al., 2005). Beberapa faktor penentu terjadinya kepatuhan adalah pasien, dukungan keluarga, efek samping obat, hubungan terapetik, dan karakteristik penyakit (Naafi et al., 2016). Ketidakpatuhan dalam pengobatan merupakan tantangan dalam manajemen pengobatan gangguan kesehatan jiwa. Pada pasien gangguan jiwa dengan tingkat penalaran dan pengetahuan yang rendah maka akan sulit untuk mengikuti instruksi regimen obat yang berakibat pada ketidakpatuhan (De Las Cuevas et al., 2017). Keluarga pasien menjadi faktor penting pada kepatuhan pasien mengingat pasien tidak dapat mengkonsumsi obat tanpa pendampingan dari keluarganya (Bolkan et al., 2013; Febriana and Setiawati, 2020; Semahegn et al., 2018). 
Pengetahuan pasien atau keluarga terhadap pengobatan berkorelasi dengan kepatuhan pasien dalam meminum obat, baik untuk gangguan kejiwaan atau penyakit kronis lainnya (Bolkan et al., 2013; Pardede, 2019; Salama et al., 2017). Pengetahuan terhadap nama, dosis, frekuensi, efek samping, dan tujuan pengobatan berkorelasi positif dengan kepatuhan (Salama et al., 2017). Kepatuhan penggunaan obat memberikan manfaat berupa outcome yang baik, mencegah kekambuhan, mengurangi kejadian masuk rumah sakit, bunuh diri, perilaku kekerasan baik terhdap diri sendiri atau lingkungan sekitarnya, peningkatan biaya kesehatan, dan kematian (Chapman and Horne, 2013; Demoz et al., 2014; Sajatovic et al., 2010). Tujuan penelitian ini untuk mengetahui hubungan antara pengetahuan informasi obat dengan kepatuhan minum obat.

\section{METODE PENELITIAN}

\section{Desain penelitian}

Penelitian ini dilakukan secara observational cross sectional pada keluarga pasien yang mendampingi ketika berobat rawat jalan di Rumah Sakit Jiwa Provinsi Lampung pada bulan September-Oktober 2019. Sampel dipilih dengan menggunakan teknik convience sampling berdasarkan kriteria inklusi yaitu responden sebagai keluarga yang hidup bersama dengan pasien yang melakukan pengobatan berulang, usia $\geq 17$ tahun, bersedia menjadi responden untuk diwawancarai mengenai pengetahuan informasi obat dan mengisi kuesioner MMAS-8. Jumlah sampel ditentukan dengan rumus Slovin, dengan tingkat kepercayaan 95\% sehingga diperoleh jumlah sampel minimal sebesar 360 responden. Penelitian ini telah memperoleh persetujuan dari Komisi Etik Poltekkes Tanjungkarang dengan nomor 275/EA/KEPK-TJK/IX/2019.

\section{Alat dan bahan}

Instrumen yang digunakan adalah panduan wawancara yang berisi pernyataan sosiodemografi, klinis (jumlah jenis obat, lama penyakit, diagnosa), 5 komponen informasi obat terdiri dari nama obat, indikasi, dosis dan frekuensi, cara pakai, dan efek samping diadopsi dari penelitian (Ramia et al., 2017) dan pernyataan kepatuhan berdasarkan pertanyaan dari MMAS-8. 


\section{Jalannya penelitian}

Rekruetmen responden

Rekruetmen responden dilakukan dengan cara peneliti mendatangi keluarga pasien. Peneliti menanyakan usia, hubungan dengan pasien sebagai kriteria inklusi. Peneliti kemudian memberikan penjelasan terkait penelitian dan proses yang akan dilakukan.

Persetujuan responden

Lembar informed consent digunakan sebagai lembar persetujuan yang menunjukkan kesediaan memberikan informasi dalam penelitian.

Pengolahan data

Data kepatuhan berdasarkan MMAS-8 diolah dengan cara menjumlahkan jawaban responden. Jika total nilai <6 sebagai kepatuhan rendah, 6-7 kepatuhan sedang, dan nilai 8 sebagai kepatuhan tinggi. Pengolahan data pengetahuan dengan cara: jika responden dapat menyampaikan $<50 \%$ dari seluruh jumlah komponen informasi maka diberi nilai 0 untuk semua komponen; $\geq 50 \%$ dari seluruh komponen informasi maka diberikan skor 1 untuk komponen yang dapat disampaikan; 100\% terhadap seluruh komponen informasi maka diberikan skor 2 untuk semua komponen yang dapat disampaikan. Total nilai dari setiap responden dijumlahkan. Total nilai 0-7 termasuk kategori suboptimal dan nilai 810 termasuk kategori optimal.

\section{Analisis Data}

Hubungan antara karakteristik dengan tingkat pengetahuan dianalisis menggunakan analisis regresi logistik dengan uji omnibus. Uji omnibus dilakukan dengan variabel bebas secara simultan. Jika nilai significancy $(\mathrm{p})<0,05$ maka terdapat hubungan antara karakteristik dengan tingkat pengetahuan. Hubungan antara tingkat pengetahuan dan tingkat kepatuhan dianalisis dengan analisis bivariat menggunakan Uji KolmogorovSmirnov. Hal ini dikarenakan hipotesis penelitian adalah komparatif, variable kategorik, dan jenis tabel adalah $2 \times 3$. Jika nilai significancy $(\mathrm{p})<0,05$ maka terdapat hubungan antara tingkat pengetahuan dan tingkat kepatuhan minum obat.

\section{HASIL DAN PEMBAHASAN}

Karakteristik responden

Berdasarkan hasil penelitian, karakteristik responden terlihat pada Tabel I. 
Tabel I. Karakteristik sosiodemografi responden

\begin{tabular}{|c|c|c|}
\hline Karakteristik & Jumlah & $\%$ \\
\hline \multicolumn{3}{|l|}{ Jenis Kelamin } \\
\hline Laki-laki & 231 & 64,2 \\
\hline Perempuan & 129 & 35,8 \\
\hline \multicolumn{3}{|l|}{ Umur } \\
\hline 17-25 (Remaja akhir) & 75 & 20,8 \\
\hline 26-35(Dewasa Awal) & 98 & 27,2 \\
\hline 36-45 (dewasa akhir) & 104 & 28,9 \\
\hline 46-55 (lansia awal) & 53 & 14,7 \\
\hline 56-65 (lansia akhir) & 26 & 7,2 \\
\hline 66 ke atas (manula) & 4 & 1,1 \\
\hline \multicolumn{3}{|l|}{ Tingkat Pendidikan } \\
\hline Tidak sekolah & 45 & 12,5 \\
\hline SD & 85 & 23,6 \\
\hline SMP & 84 & 23,3 \\
\hline SMA & 122 & 33,9 \\
\hline $\mathrm{S} 1$ & 23 & 6,4 \\
\hline $\mathrm{S} 2$ & 1 & 0,3 \\
\hline \multicolumn{3}{|l|}{ Status pembiayaan } \\
\hline Asuransi & 311 & 86,4 \\
\hline Biaya sendiri (out of pocket) & 49 & 13,6 \\
\hline \multicolumn{3}{|l|}{ Jumlah anggota keluarga } \\
\hline 2 & 60 & 16,7 \\
\hline 3 & 103 & 28,6 \\
\hline 4 & 100 & 27,8 \\
\hline 5 & 54 & 15 \\
\hline 6 & 26 & 7,2 \\
\hline 7 & 13 & 3,6 \\
\hline 8 & 3 & 0,8 \\
\hline 9 & 1 & 0,3 \\
\hline \multicolumn{3}{|l|}{ Penghasilan } \\
\hline$<\operatorname{Rp} 2.241 .300$ & 265 & 73,6 \\
\hline$\geq \operatorname{Rp} 2.241 .300$ & 95 & 26,4 \\
\hline
\end{tabular}

Responden dalam penelitian ini berstatus sebagai anggota keluarga terdiri dari 64,2\% laki-laki dan 35,8\% perempuan, dengan rentang usia 17-86 tahun. Tingkat pendidikan responden bervariasi dari tidak bersekolah hingga Magister (S2). Karakteristik pasien meliputi data status pembiayaan, diagnosa, jumlah jenis obat yang diresepkan, dan lama penyakit. Pembiayaan berobat jalan pasien sebagian besar menggunakan pembiayaan asuransi, baik mandiri atau bantuan dari pemerintah, sedangkan pasien yang mengeluarkan biaya sendiri atau out of pocket $(13,6 \%)$. Pembayaran kesehatan out of pocket tetap menjadi pilihan masyarakat dapat disebabkan karena masyarakat mencari pelayanan kesehatan apabila memerlukan saja (Kurniawan et 
al., 2011). Pembayaran out of pocket berpotensi menyebabkan masalah keuangan rumah tangga akibat besarnya biaya pengobatan (Tarigan, 2017). Keuangan rumah tangga, biaya pengobatan pada penyakit/fasilitas khusus baik biaya langsung atau tidak langsung, serta ketidakikutsertaan atau cakupan pengobatan yang tidak memadai dalam sistem jaminan kesehatan nasional dapat berdampak pada ketidakpatuhan (Semahegn et al., 2018). Survey yang dilakukan kepada pengguna layanan Medicare menunjukkan bahwa ketidakpatuhan berupa tidak melakukan pengobatan berulang/menebus resep dikarenakan biaya yang tinggi 55,5\%, obat tidak dicover asuransi 20,2\%, merasa tidak perlu dengan obat tersebut (18\%), dan takut akibat efek samping $(11,8 \%)$ (Iuga and Mcguire, 2014). Karakteristik klinis pasien terlihat pada Tabel II.

Tabel II. Karakteristik klinis pasien

\begin{tabular}{lcc}
\hline Karakteristik & Jumlah & \% \\
\hline Jumlah jenis obat & 4 & 1,1 \\
1 & 19 & 5,3 \\
2 & 140 & 38,9 \\
3 & 154 & 42,8 \\
4 & 35 & 9,7 \\
5 & 7 & 1,9 \\
6 & 1 & 0,3 \\
7 & & \\
Lama penyakit (bulan) & 34 & 9,4 \\
Akut (<12) & 326 & 90,6 \\
Kronis ( $\geq 12$ ) & & \\
Diagnosa & 207 & 57,5 \\
Skizofrenia, gangguan skizo tipikal dan gangguan & & \\
waham & 32 & 8,9 \\
Halusinasi & 29 & 8,1 \\
Harga diri rendah & 22 & 6,1 \\
Kelainan jiwa lain akibat kerusakan otak atau & & \\
penyakit badan, jenis lainnya & 22 & 6,1 \\
Gangguan mental organic & 21 & 5,8 \\
$\quad$ Gangguan kepribadian dan perilaku masa dewasa & 27 & 13,6 \\
$\quad$ Lainnya
\end{tabular}

Hasil pada Tabel II yaitu jenis diagnosa yang paling banyak pada penelitian ini adalah skizofrenia dan gangguan waham sebesar 57,5\%. Skizofrenia merupakan gangguan kejiwaan nomor tiga $(4,7 \%)$ di dunia setelah depresi $(77,8 \%)$ dan bipolar disorder (13,3\%) (Semahegn et al., 2018). Gangguan kejiwaan yang dialami pasien bersifat kronis $(90,6 \%)$, yaitu telah dialami lebih dari 12 bulan terhitung hingga dilakukan penelitian. Gangguan kejiwaan bukan merupakan penyakit yang onsetnya terjadi cepat dengan durasi penyakit yang singkat. Gangguan kejiwaan yang berlangsung lama sebagai 
faktor komorbiditas pada penyakit fisik yang bersifat kronis, seperti penyakit jantung dan pembuluh darah, obesitas, penyakit paru obstruksi kronis, diabetes, dan kanker (Vos et al, 2016).

Prevalensi depresi pada penyakit fisik kronis (kanker, penyakit jantung, penyakit ginjal, dan PPOK) berkisar 13-79\%, variasi tergantung pada pasien rawat inap atau rawat jalan (Daré et al., 2019). Penyakit kronis merupakan penyakit tidak menular, dalam jangka waktu lama, yang tidak dapat diatasi secara spontan, dan pada umunya jarang sembuh total (Vigo et al., 2018). Penyakit fisik kronis sebaliknya, dapat menjadi faktor komorbiditas pada penyakit gangguan kejiwaan, seperti diabetes dan obesitas (Daré et al., 2019). Pada pasien depresi, prevalensi terjadinya obesitas sebesar $19 \%$ dan $42,1 \%$ pada pasien skizofrenia. Terjadinya diabetes mellitus memiliki prevalensi 4-5 kali lebih tinggi pada pasien skizofrenia dan 3 kali lebih tinggi pada pasien bipolar dibandingkan dengan populasi yang bersifat umum (Daré et al., 2019).

Penelitian yang dilakukan di Inggris menunjukkan bahwa peresepan obat yang digunakan untuk gangguan jiwa meningkat $6,8 \%$ per tahun dengan antidepresan yang paling banyak digunakan, diikuti dengan hipnotik-anxiolitik, dan antipsikotik (Ilyas and Moncrieff, 2012). Jumlah jenis obat yang diresepkan pada pasien rawat jalan dalam penelitian ini berkisar 1-7 obat. Rata-rata jumlah jenis obat yang diresepkan sebesar $3,6 \pm 0,87$. Nilai tersebut lebih tinggi dibandingkan penelitian yang dilakukan pada pasien

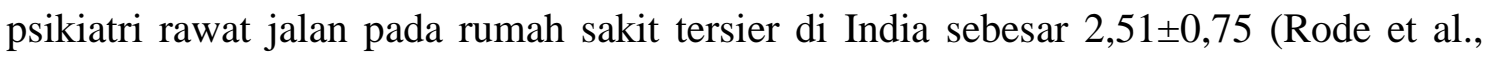
2014). Kompleksitas pengobatan seperti frekuensi minum obat lebih dari satu kali sehari, penggunaan kombinasi obat berdampak negatif pada kepatuhan pasien psikiatri (Chapman and Horne, 2013; Semahegn et al., 2018).

Distribusi Frekuensi Tingkat Pengetahuan

Hasil penelitian mengenai tingkat pengetahuan seperti pada Gambar 1 dan Tabel III. 


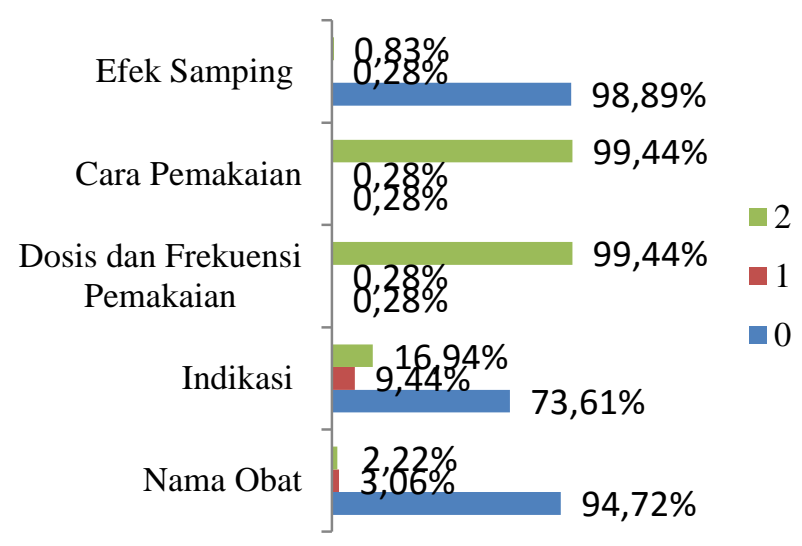

Gambar 1. Pengetahuan terhadap komponen informasi obat

Tabel III. Distribusi tingkat pengetahuan

\begin{tabular}{lcc}
\hline Tingkat Pengetahuan & Frekuensi & \% \\
\hline suboptimal & 357 & 99,2 \\
optimal & 3 & 0,8 \\
\hline Total & 360 & 100 \\
\hline
\end{tabular}

Sebagian besar pengetahuan responden berada pada kategori suboptimal $(99,2 \%)$ (Tabel 3). Analisis pengetahuan responden per komponen informasi obat diperoleh hasil 99,4\% responden mengetahui cara pemakaian, dosis, dan frekuensi penggunaan obat. Komponen informasi yang terendah yang diketahui responden adalah efek samping $(0,83 \%)$

Penelitian yang dilakukan Ramia (2017) terhadap 905 responden di apotek menunjukkan sebagian besar mengetahui pengetahuan suboptimal 55,7\% dan pengetahuan optimal $38,8 \%$. Komponen informasi yang paling banyak diketahui adalah nama obat sebesar $82 \%$ dan paling rendah adalah efek samping obat $(0,83 \%)$. Pengetahuan terhadap obat-obatan yang kurang akan mempengaruhi kepatuhan minum obat (Chapman and Horne, 2013; Yap et al., 2016).

Distribusi frekuensi tingkat kepatuhan pasien

Hasil distribusi frekuensi tingkat kepatuhan pasien pada penelitian terlihat pada Tabel IV. 
Tabel IV. Distribusi frekuensi tingkat kepatuhan

\begin{tabular}{lcc}
\hline Tingkat Kepatuhan $*$ & Jumlah & $\%$ \\
\hline Kurang & 61 & 16,9 \\
Sedang & 56 & 15,6 \\
Baik & 243 & 67,5 \\
Total & 360 & 100,0
\end{tabular}

Total nilai MMAS-8 kurang dari 6 berarti kurang, 6-7 tingkat pengetahuan sedang, dan 8 tingkat pengetahuan baik.

Tingkat kepatuhan dengan menggunakan kuesioner MMAS-8 menunjukkan tingkat kepatuhan yang baik sebesar 67,5\% responden, seperti pada Tabel V. Hasil ini masih tergolong rendah jika dibandingkan batas minimal kepatuhan secara umum, yaitu $\geq 80 \%$ (Demoz et al., 2014). Kepatuhan pada pasien psikiatri berkisar 24-90\% pada pasien yang menggunakan antipsikosis dan 40-90\% yang menggunakan antidepresan (Demoz et al., 2014). Ketidakpatuhan pada pasien skizofrenia melebihi $60 \%$ dan pada pasien bipolar berkisar 20-50\% (Sajatovic et al., 2010). Kepatuhan pada pasien psikiatri khususnya schizophrenia memiliki pola yang berbeda, dikaitkan dengan jenis antipsikotis yang digunakan (Chapman and Horne, 2013).

Hubungan antara karakteristik sosioekonomi-klinis terhadap tingkat pengetahuan

Uji statistik untuk menguji korelasi secara simultan antara karakteristik sosiodemografi dan klinis dengan menggunakan analisis regresi logistik uji omnibus dengan taraf signifikansi 0,05 dan hasilnya dapat dilihat pada Tabel V. Tidak terdapat pengaruh yang signifikan dari 9 variabel independen secara simultan terhadap variabel dependen (tingkat pengetahuan). Hal ini terlihat dari nilai omnibus 0,964 (lebih besar dari 0,05). Oleh karena itu, uji multivariat terhadap variable independen yang mempengaruhi tidak dilakukan. 
Tabel V. Hasil uji hubungan antara karakteristik sosioekonomi-klinis terhadap tingkat pengetahuan

\begin{tabular}{lrc}
\hline Parameter & p \\
\hline Sosiodemografi & Jenis Kelamin & \\
& Umur & 0,964 \\
& Tingkat Pendidikan & \\
Status Pembiayaan & \\
Klinis & Jumlah Anggota Keluarga & \\
& Jumlah Penghasilan & 0,964 \\
& Jumlah Obat & \\
& Lama Penyakit & \\
Diagnosa & \\
\hline
\end{tabular}

Karakteristik sosioekonomi dan klinis yang diukur pada penelitian ini secara simultan tidak mempengaruhi secara signifikan terhadap terhadap tingkat pengetahuan pasien $(\mathrm{p}>0,05)$. Pengetahuan keluarga pasien pada penelitian ini dalam kategori suboptimal sebesar 99,2\% dan optimal 0,8\%. Lima komponen yang diukur terkait pengetahuan penggunaan obat pada penelitian ini yaitu nama obat, indikasi, dosis dan frekuensi pemakaian, cara pakai, dan efek samping. Komponen informasi yang paling banyak diketahui keluarga pasien adalah dosis dan frekuensi pemakaian serta cara pakai $(99,4 \%)$, kemudian indikasi $(16,9 \%)$, nama obat $(2,22 \%)$, efek samping $(0,8 \%)$. Hal ini diperkuat oleh penelitian yang dilakukan Okuyan et al (2012), menunjukkan hasil bahwa persentase partisipan yang menyebutkan dengan benar nama, dosis, indikasi, dan efek samping masing masing sebesar 55,8\%, 93,4\%, 78,8\%, dan 11,7\%. Jika pasien tidak peduli terhadap nama dan kekuatan sediaan dari obat yang dikonsumsi, pasien dapat mengkonsumsi obat yang salah, kekuatan sediaan obat yang salah, dan mungkin saja terjadi duplikasi dari obat yang berbeda merk saja. Pasien tidak bisa memeriksa obat yang telah dibeli apakah telah sesuai atau belum, atau pasien tidak bisa berkomunikasi tentang obat yang mereka gunakan ketika diperlukan. Jika instruksi pengobatan tidak dipahami, maka pasien dapat saja mengkonsumsi obat dengan waktu, dosis, dan rute yang salah (Blignaut et al., 2016).

Studi yang dilakukan Dawooda et al. (2017) yang melakukan penelitian terhadap faktor yang mempengaruhi pengetahuan dalam penggunaan obat menunjukkan bahwa sebagian besar responden memiliki pengetahuan yang cukup tentang penggunaan obat. Faktor yang secara signifikan mempengaruhi dalam penelitian tersebut adalah usia, jenis kelamin wanita, tingkat pendidikan tinggi, pendapatan bulanan yang lebih tinggi dan 
responden dengan penyakit kronis (Dawood et al., 2017). Selain itu, pengetahuan mengenai obat juga didasarkan pada jenis resep, yaitu resep baru dan resep ulang. Pasien dengan terapi obat jangka panjang (resep berulang ) dapat memiliki pengetahuan yang lebih tinggi dikarenakan pengalaman penggunaan (Manchanayake et al., 2018). Berbeda dengan penelitian Horvart et al (2015) tentang kontribusi konseling apoteker dalam pengetahuan pasien atas obat yang diresepkan di Slovania. Pasien dengan resep baru memiliki pengetahuan yang berbeda signifikan dibandingkan pasien dengan resep ulang. Pasien dengan resep baru mendapatkan konseling yang lebih baik dibandingkan pasien resep berulang. Hal ini dapat disebabkan kurang tertariknya pasien dan kurang kepercayaan bahwa konseling diperlukan. Penyebab lainnya bahwa pasien dengan kondisi kronis (resep berulang) mengetahui cara menggunakan obat yang tepat (Horvat and Kos, 2015). Dalam penelitian ini, 90,6\% pasien dengan kondisi kronis ( $\geq 12$ bulan).

Uji hubungan antara tingkat pengetahuan terhadap kepatuhan minum obat

Uji statistik untuk menguji hubungan antara tingkat pengetahuan terhadap kepatuhan minum obat dianalisis menggunakan uji Kolmogorov-Smirnov dengan taraf signifikansi 0,05 dan hasil dapat dilihat pada tabel VI. Nilai significancy menunjukkan angka 0,594. Oleh karena $\mathrm{p}>0,05$ maka dapat disimpulkan bahwa tidak ada hubungan signifikan antara tingkat pengetahuan dengan tingkat kepatuhan minum obat.

Tabel VI. Hasil uji hubungan antara tingkat pengetahuan dan kepatuhan

\section{Tingkat Kepatuhan}

\begin{tabular}{lccccccc} 
& \multicolumn{2}{c}{ Kurang } & \multicolumn{2}{c}{ Sedang } & \multicolumn{2}{c}{ Baik } & \multirow{2}{*}{$\boldsymbol{p}$} \\
\cline { 2 - 6 } & $\mathrm{n}$ & $\%$ & $\mathrm{n}$ & $\%$ & $\mathrm{n}$ & $\%$ & \\
\hline Suboptimal & 60 & 98,4 & 55 & 98,2 & 242 & 99,6 & 0,594 \\
Optimal & 1 & 1,6 & 1 & 1,8 & 1 & 0,4 & \\
\hline Total & 61 & 100,0 & 56 & 100,0 & 243 & 100,0 & \\
\cline { 2 - 6 } & & & & & & &
\end{tabular}

Hubungan yang tidak signifikan pada tingkat pengetahuan dengan tingkat kepatuhan pasien pada penelitian ini sesuai dengan penelitian lainnya, diduga erat kaitannya dengan wilayah demografi pasien yang berobat dengan rumah sakit jiwa tempat berobat mempengaruhi faktor sosio-kultur yang melatar belakangi pasien sehingga respon pasien terhadap masing-masing variabel yang diukur cenderung homogen. Selain itu juga faktor pendampingan keluarga/perawat yang membantu dalam memantau pengobatan sudah berlangsung dengan baik (Dawood et al., 2017). Ketidakpatuhan dalam 
pengobatan pasien psikiatri dapat disebabkan beberapa faktor, yaitu perilaku pasien, dukungan sosial atau keluarga, penyakit dan terapi pengobatannya, serta sistem jaminan kesehatan (Semahegn et al., 2018). Selain itu, kondisi komorbid juga dapat meningkatkan ketidakpatuhan. Depresi disertai penyalahgunaan obat telah dihubungkan dengan ketidakpatuhan diantara penyakit psikiatri lainnya. Penyakit psikiatri sebagai faktor resiko juga terhadap ketidakpatuhan pada pasien yang dengan penyakit fisik. Komorbid ini akan menjadikan regimen pengobatan menjadi lebih komplek (Chapman and Horne, 2013).

Faktor dari keluarga pasien seperti jenis kelamin, umur, tingkat pendidikan, status pembiayaan, penghasilan, dan jumlah anggota keluarga tidak mempengaruhi secara signifikan dalam penelitian ini. Perilaku anggota keluarga seperti biaya transportasi ke rumah sakit, keharmonisan dalam keluarga, rutinitas pekerjaan rumah tangga, agama, kekurangan pendamping pengobatan atau berusia tua, rendahnya kepatuhan keluarga untuk berobat ulang sebagai faktor yang mempengaruhi ketidakpatuhan (Semahegn et al., 2020). Penelitian lain pada penyakit non-psikiatri, faktor ketidakpatuhan pengobatan berupa kompleksitas regimen pengobatan, kurangnya pengetahuan tentang penyakit dan terapi, kesulitan mengingat untuk mengambil obat, minum banyak obat pada saat yang sama (Roy et al., 2005). Penelitian lain pada kelompok pasien hipertensi menyatakan bahwa tingkat pengetahuan (yang diukur meliputi frekuensi dan lama penggunaan obat) yang lebih tinggi berkorelasi dengan tingkat kepatuhan yang baik (Jankowska-Polańska et al., 2016). Sama halnya dengan penelitian pada pasien penyakit kronis yang menyatakan bahwa adanya korelasi yang signifikan antara total nilai pengetahuan dengan kepatuhan pada pasien di 60 apotek di Istanbul (Maguire et al., 2007).

Pemantauan kepatuhan pasien merupakan isu dalam kesehatan yang terus menerus dilakukan. Akan tetapi, pengukurannya dalam menentukan tingkat kepatuhan memiliki keterbatasan, yang terbagi menjadi langsung dan tidak langsung. Metode tidak langsung dapat berupa menanyakan ke pasien (paling mudah namun tingkat kepercayaan rendah) (Kane et al., 2013).

\section{KESIMPULAN}

Pengetahuan informasi obat dengan kepatuhan minum obat pasien gangguan jiwa di provinsi Lampung tidak terdapat hubungan siginifikan. 


\section{UCAPAN TERIMA KASIH}

Terima kasih juga kepada Politeknik Kesehatan Tanjungkarang yang telah memberikan bantuan dana melalui skema penelitian dosen pemula.

\section{DAFTAR PUSTAKA}

Blignaut, Alwiena J; Coetzee, S. K. ; K. H. C. (2016). Medication administration errors and realted deviations from safe practice :an observational study. Journal of Clinical Nursing, 26(21-22), 3610-3623

Bolkan, C. R., Bonner, L. M., Campbell, D. G., Lanto, A., Zivin, K., Chaney, E., \& Rubenstein, L. V. (2013). Family involvement, medication adherence, and depression outcomes among patients in veterans affairs primary care. Psychiatric Services, 64(5), 472-478.

Chapman, S. C. E., \& Horne, R. (2013). Medication nonadherence and psychiatry. Current Opinion in Psychiatry, 26(5), 446-452.

Daré, L. O., Bruand, P., Gérard, D., Marin, B., \& Lameyre, V. (2019). Co-morbidities of mental disorders and chronic physical diseases in developing and emerging countries : a meta-analysis, $1-12$.

Dawood, O. T., Hassali, M. A., \& Saleem, F. (2017). Factors affecting knowledge and practice of medicine use among the general public in the State of Penang, Malaysia. Journal of Pharmaceutical Health Services Research, 8(1), 51-57.

De Las Cuevas, C., De Leon, J., Peñate, W., \& Betancort, M. (2017). Factors influencing adherence to psychopharmacological medications in psychiatric patients: A structural equation modeling approach. Patient Preference and Adherence, 11, 681690.

Demoz, Z., Legesse, B., Teklay, G., Demeke, B., Eyob, T., Shewamene, Z., \& Abera, M. (2014). Medication adherence and its determinants among psychiatric patients in an Ethiopian referral hospital. Patient Preference and Adherence, 8, 1329-1335. 
Febriana, B., \& Setiawati, W. E. (2020). Family Support is the Key to Compliance with the Treatment of Relapsing Schizophrenia Patients. Jurnal Ners, 15(2), 457-461.

Horvat, N., \& Kos, M. (2015). Contribution of Slovenian community pharmacist counseling to patients ' knowledge about their prescription medicines : a crosssectional study, 41-49.

Ilyas, S., \& Moncrieff, J. (2012). Trends in prescriptions and costs of drugs for mental

Iuga, A. O., \& Mcguire, M. J. (2014). Adherence and health care costs, 35-44.

Jankowska-Polańska, B., Uchmanowicz, I., Dudek, K., \& Mazur, G. (2016). Relationship between patients' knowledge and medication adherence among patients with hypertension. Patient Preference and Adherence, 10, 2437-2447.

Kane-, J. O. H. N. M., Ishimoto, T. A. K., \& Orrell-, C. H. U. C. (2013). Disorders : determinants and management non-adherence to medication in patients with psychotic disorders : epidemiology, contributing factors and management strategies. World Psychiatric, 12(October), 216-226.

Kurniawan, A., Intiasari, A. D., Kesehatan, J., Fakultas, M., Kesehatan, I., \& Jenderal, U. (2011). Health Financing Analysis of Thalassemia Patient Family, 471-476.

Maguire, A., Douglas, I., Smeeth, L., \& Thompson, M. (2007). Determinants of cholesterol and triglycerides recording in patients treated with lipid lowering therapy in UK primary care. Pharmacoepidemiology and Drug Safety, 16, 228-228.

Manchanayake, M. G. C. A., Bandara, G. R. W. S. K., \& Samaranayake, N. R. (2018). Patients' ability to read and understand dosing instructions of their own medicines - a cross sectional study in a hospital and community pharmacy setting, 1-8.

Marquez, P. V, \& Saxena, S. (2016). Making Mental Health a Global Priority. Cerebrum : The Dana Forum on Brain Science, 2016(August), 1-14. 
Naafi, A. M., Perwitasari, D. A., \& Darmawan, E. (2016). Kepatuhan Minum Obat Pasien Rawat Jalan Skizofrenia Di Rumah Sakit Jiwa Prof. Dr. Soerojo Magelang. Kartika Jurnal Ilmiah Farmasi, 4(2), 7-12.

Pardede, J. A. (2019). Family Knowledge about Hallucination Related to Drinking Medication Adherence on Schizophrenia Patient. Jurnal Penelitian Perawat Profesional, 2(4), 399-408.

Ramia, E., Zeenny, R. M., Hallit, S., \& Salameh, P. (2017). Assessment of patients' knowledge and practices regarding their medication use and risks in Lebanon. International Journal of Clinical Pharmacy, 39(5), 1084-1094.

Rode, S. B., Ajagallay, R. K., Salankar, H. V, \& Sinha, U. (2014). IJBCP International Journal of Basic \& Clinical Pharmacology A study on drug prescribing pattern in psychiatry out-patient department from a tertiary care teaching hospital, 3(3), 517522.

Roy, R., Jahan, M., Kumari, S., \& Chakraborty, P. (2005). Reasons for drug noncompliance of psychiatric patients: A centre based study. Journal of the Indian Academy of Applied Psychology, 31(1-2), 24-28.

Sajatovic, M., Velligan, D. I., Weiden, P. J., Valenstein, M. A., \& Ogedegbe, G. (2010). Measurement of psychiatric treatment adherence. Journal of Psychosomatic Research, 69(6), 591-599.

Salama, A., Yasin, A. E.-R., \& Elbarbary, W. (2017). Medication knowledge as a determinant of medication adherence in geriatric patients, Serse Elian City, Menoufia Governorate, Egypt. Menoufia Medical Journal, 30(1), 63.

Semahegn, A., Torpey, K., Manu, A., Assefa, N., Tesfaye, G., \& Ankomah, A. (2018). Psychotropic medication non-adherence and associated factors among adult patients with major psychiatric disorders : a protocol for a systematic review, 1-5. 
Semahegn, A., Torpey, K., Manu, A., Assefa, N., Tesfaye, G., \& Ankomah, A. (2020). Psychotropic medication non-adherence and its associated factors among patients with major psychiatric disorders: A systematic review and meta-analysis. Systematic Reviews, 9(1), 1-18.

Tarigan, I. (2017). Gambaran Out of Pocket pada Awal Era JKN di Indonesia Description Out of Pocket in the Early Era JKN at Indonesia. Jurnal Penelitian Dan Pengembangan Pelayanan Kesehatan, 1(2), 141-146.

Vigo, D., Thornicroft, G., \& Atun, R. (2018). Estimating the true global burden of mental illness. The Lancet Psychiatry, 3(2), 171-178.

Vos, T., Allen, C., Arora, M., Barber, R. M., Bhutta, Z. A., Brown, A., ... Chen, A. Z. et all. (2016). Global, regional, and national incidence, prevalence, and years lived with disability for 310 diseases and injuries , 1990 - 2015 : a systematic analysis for the Global Burden of Disease Study 2015. Vos, T., Allen, C., Arora, M., Barber, R. M., Bhutta, Z. A., Brown, A., ... Chen, A. Z. et All, 1990-2015.

Yap, A. F., Thirumoorthy, T., \& Kwan, Y. H. (2016). Medication adherence in the elderly. Journal of Clinical Gerontology and Geriatrics, 7(2), 64-67. 